\title{
The Influence of the Sick House Syndrome on Nasal Mucosa and Nasal Symptoms
}

\author{
Chan Hum Park ${ }^{1,2}$, Young Gil Ko ${ }^{1}$, Jun Ho Lee ${ }^{1}$, Seok Min Hong ${ }^{1}$ and Jung Woo Lee ${ }^{1}$ \\ ${ }^{1}$ Department of Otorhinolaryngology-Head and Neck Surgery, College of Medicine, Hallym University, Chuncheon; and \\ ${ }^{2}$ Facial Skeleton Bio Institute, Hallym University, Chuncheon, Korea
}

\section{새집증후군이 비점막과 비증상에 미치는 영향}

박찬흠 $^{1,2} \cdot$ 고영길 $^{1} \cdot$ 이준호 $^{1} \cdot$ 홍석민 $^{1} \cdot$ 이정우 ${ }^{1}$

한림대학교 의과대학 이비인후과학교실, ${ }^{1}$ 한림대학교 안면골격 바이오 연구소 ${ }^{2}$

Received January 16, 2011

Revised March 9, 2011

Accepted March 18, 2011

Address for correspondence

Chan Hum Park, MD, PhD

Department of Otorhinolaryngology-

Head and Neck Surgery,

College of Medicine,

Hallym University,

153 Gyo-dong, Chuncheon 200-704,

Korea

Tel $+82-33-240-5181$

Fax $+82-33-241-2909$

E-mail hlpch@paran.com
Background and Objectives Concerns about the quality of indoor air have increased recently. However, there has not been any significant research conducted concerning the patterns of histologic and organic changes induced in humans by indoor air pollution. The aim of the study is to investigate the organic changes of nasal mucosa and nasal symptoms due to exposed concentrations of indoor air pollution.

Subjects and Method We studied fourteen people from four families, all of whom had plans to move into new apartments. We measured the quantities of indoor air pollution before their move, one week after moving in, and then one month after the move. Other clinical tests such as an acoustic rhinometry, olfactory tests and nasal smears were performed.

Results Mean concentrations of Total Volatile Organic Chemicals (TVOCs) and aldehydes showed an increase after moving into the new apartments. Post-move acoustic rhinometry, Connecticut Chemosensory Clinical Research Center (CCCRC) test and endoscopic findings showed a decrease in nasal function and patency. Additionally, in nasal smears, eosinophils with bilobulated nuclei were observed, and eosinophil count showed a pattern of increase. Conclusion High concentrations of indoor air pollutants could induce organic changes of the nasal cavities and cause the recession of olfactory function. Due to indoor air pollutants, hypersensitivity of nasal mucosa was induced, and histological changes of nasal mucosa as well as hematological changes were observed. These indicate that indoor air pollution impinges on the nasal mucosa and cause nasal symptoms.

Korean J Otorhinolaryngol-Head Neck Surg 2011;54:265-70

Key Words Indoor air pollution $\cdot$ Sick building syndrome $\cdot$ Allergic rhinitis.

\section{서 론}

인구의 도시 집중화, 주택 형태의 변화, 생활 방식의 변화 등으로 인해 현대 인간은 보다 많은 시간을 실내에서 보내게 되었다. 이로 인해 실내 공기의 질은 일정 부분 건강을 위협 하는 많은 질환과 밀접한 관계가 있음이 보고되고 있으며, ${ }^{1,2)}$ 이에 대한 관심도 점차 고조되고 있다. 많은 사람들이 신축 건축물에서 일정 시간을 보낸 후 두통, 현훈, 피부 가려움 등
의 증상을 경험한다. 실내 공기의 오염과 이러한 증상들과 의 연관성에 관한 연구들이 지속적으로 보고되고 있으며 ${ }^{3,4)}$ 이와 관련하여 "새집증후군" ${ }^{5)}$ 이란 용어를 사용하고 있다.

새집증후군은 명확한 의학적 정의가 있는 용어는 아니다. 이는 특정 건축물 종사자들에게 있어 건강상의 혹은 생활 상의 지장을 초래하는 여러 증상들에 대한 증례에 기초하여 만들어진 용어이다. ${ }^{6)}$ 전형적 증상으로는 두통, 피로 및 피부, 안구, 비강, 인후두 부위의 자극 증상 등이 있다. ${ }^{7)}$ 
현재까지 실내 공기의 오염과 호흡기, 알레르기 질환과의 연관성에 관련한 여러 보고들이 있었으며, 신축 건축물의 실 내 공기 오염은 입주자들에게 여러 다양한 증상들을 유발 한다고 보고되었다. ${ }^{89)}$ 그러나 아직까지 국내에서는 이러한 실내 공기 오염으로 인해 발생하는 비점막과 비증상의 변화 를 관찰한 연구는 전무한 상태이다. 본 연구에서는 대표적 실내 공기 오염 물질로 알려진 알데히드 화합물과 휘발성 유기 화합물의 농도 변화에 따른 비강내 점막 조직의 변화 를 내시경과 비즙도말 검사를 통하여 확인하고, 대상자들의 자각 증상이 어떻게 변화하는지 확인하여 새집증후군이 비 점막과 비증상에 어떠한 영향을 미치는지 증명하기 위해 계 획하였다.

\section{대상 및 방법}

\section{대 상}

신축 공동 주택으로의 이사를 계획하고 있는 4 가구 14 명 을 대상으로 본 연구를 계획하였다. 먼저 이사 전 거주지의 실내 공기에 존재하는 알데히드 화합물과 휘발성 유기 화합 물의 농도를 측정하고, 대상자들이 본원에 내원하여 임상 검사를 시행하였다. 이사 1 주 후와 1 개월 후에도 이사 전과 동일한 방법으로 실내 공기내 오염 물질의 농도를 측정하고, 외래에 내원하여 임상 검사를 시행하는 방식으로 연구를 진 행하였다.

\section{방 법}

\section{실내 공기 측정 방법}

30 분간 모든 문을 활짝 열어 환기시킨 후 5 시간 동안 문 을 닫고 마지막 30 분간 실내 공기를 측정하였다. 휘발성 유 기 화합물은 Tenax-TA흡착관(SUPELCO, Bellefonte, $\mathrm{PA}, \mathrm{USA}$ )을 이용하여 $150 \mathrm{~mL} / \mathrm{min}$ 의 유속으로 30 분간 4.5 L를 포집한 후 Thermal desorption(TD, KnR, Korea)Gas chromatography/Flame ionization detector(GC/ FID, HP, Canton, MA, USA)을 이용하여 분석하였다. 메 틸아세틸케톤, 에틸벤젠, 자일렌, 스티렌, 톨루엔 각각의 농 도가 분석되었고, 총 휘발성 유기 화합물의 농도가 분석되 었다. 알데히드기 화합물은 Tenax-TA 흡착관을 이용하여 $150 \mathrm{~mL} / \mathrm{min}$ 의 유속으로 30 분간 $9 \mathrm{~L}$ 를 포집한 후 HPLC (high performance liquid chromatography, Waters, Milford, MA, USA)을 통해 폼알데히드, 아세트알데히드 농 도를 각각 분석하였다.

\section{문진, 이학적 검사}

이사 전 대상자들에 대해 과거 병력을 확인하고 비증상에 대한 문진을 시행한 후 디지털 카메라와 0 도 비내시경(4 $\mathrm{mm}$ )을 이용하여 사진 촬영을 시행하였다. 이사 1 주 및 1 개 월 후 동일 문진과 이학적 검사를 반복하여 대상자들의 점수 를 합산하여 평균값을 구하였다. 증상의 평가를 위하여 비 루, 비특이적 증상(두통 혹은 피곤감), 원격 증상(안구 혹은 피부 자극 증상)을 평가 항목으로 설문하여 점수화하였다. 비 루 증상을 평가하기 위하여 $0=$ 증상이 없음(no complaint), $1=$ 수양성 분비물, $2=$ 점액성 및 농성 분비물로 평가하였고, 비특이적 증상에 대해 $0=$ 두통 및 피곤감 없음, $1=$ 두통과 피 곤감 중 1 가지의 비특이적 증상 존재, $2=$ 두통과 피곤감 모두 존재로 분류하여 평가하였고, 원격 증상에 대해 $0=$ 안구 및 피부 원격 증상 없음, $1=$ 안구 자극 증상과 피부 자극 증상 중 1 가지의 원격 증상 존재, $2=$ 안구 자극 증상, 피부 자극증 상 모두 존재로 분류하여 평가하였다. 비강 사진을 기초로 비 점막의 부종과 발적에 대해 반정량적으로 단계를 나누어 $0=$ 변화 없음, $1=$ 경도의 변화, $2=$ 중등도의 변화로 분류하여 각 각 평가하였고, 비루에 대해 $0=$ 없음, $1=$ 있음으로 분류하여 각 대상자들의 점수를 합산하여 평균값을 구하였다. 통계 분 석으로 paired t-test를 사용하였고 통계 프로그램으로 SPSS 12.0(SPSS Inc, Chicago, IL, USA)을 이용하였다.

\section{음향비강통기도검사}

비강의 최소 단면적과 부피를 측정하고 기능적 변화를 확 인하여 이사 전과 이사 1 주 후, 1 개월 후를 비교 하였다. 상기 결과에 대한 통계적 분석은 Paired t-test를 이용하였다.

\section{후각기능검사}

후각 인지 및 역치를 측정하기 위하여 Connecticut Chemosensory Clinical Research Center test(CCCRC test) 와 T\&T olfactometer를 사용하였다. 상기 결과에 대한 통 계적 분석은 Paired t-test를 이용하였다.

\section{비즙도말검사}

면봉을 이용하여 하비갑개의 중간 부위에서 비분비물을 체취, 도말하여 hematoxylin-eosin(H-E) 염색 후 세포학 적 변화를 확인하였다. 염색된 표본은 광학 현미경하에서 (×1,000배) 무작위로 10 개의 시야를 선정하여 침윤된 호산 구의 수를 세는 방법으로 시행하였다.

\section{Multiple Allergen Simultaneous Test(MAST) \\ 이사 전과 이사 1 주 후 대상자들의 혈액을 체취하여 검사}


하였고, 결과에 대한 통계적 분석은 Paired t-test를 이용 하였다. $\mathrm{IgE}$ 항체가 검출되는 특이 항원의 개수를 측정하기 위하여 $0.35 \mathrm{IU} / \mathrm{mL}$ 이상의 $\mathrm{IgE}$ 값을 기준으로 시행 하였다.

\section{결 과}

\section{실내 공기 오염 측정}

이사 전과 비교하여 이사 1 주 후 실내 공기 오염 물질의 농 도 증가를 확인할 수 있었다(Figs. 1 and 2). 이사 1주 후 휘 발성 유기 화합물의 총 농도는 이사 전과 비교하여 평균 5 배 상승하였고, 이사 1 개월 후 다소 감소하였으나 이사 전과 비교하여 여전히 2.5배 높게 측정되었다(Fig. 1). 메틸에틸 케톤, 에틸벤젠, 자일렌, 스티렌, 톨루엔과 같은 5 가지 주요 휘발성 유기 화합물의 농도 역시 이사 전과 비교하여 이사 1 주 후와 1 개월 후 각각 13.4 배와 6.3배 증가하였다(Table 1). 포름알데히드, 아세트알데히드의 농도는 신축공동주택으로 이사 1 개월 후 증가를 보였으나 유의할 만한 수준은 아니었 다(Fig. 2).

\section{문진 및 이학적 검사}

비강 내 해부학적 구조의 이상은 모든 대상자에서 관찰되 지 않았으나, 두 명의 소아 대상자들에게(C3, D3 대상자) (Table 2) 알레르기 비염의 기왕력이 있었다. 신축 공동 주 택으로 이사 1 주와 1 개월 후 대부분의 대상자들은 비루, 두

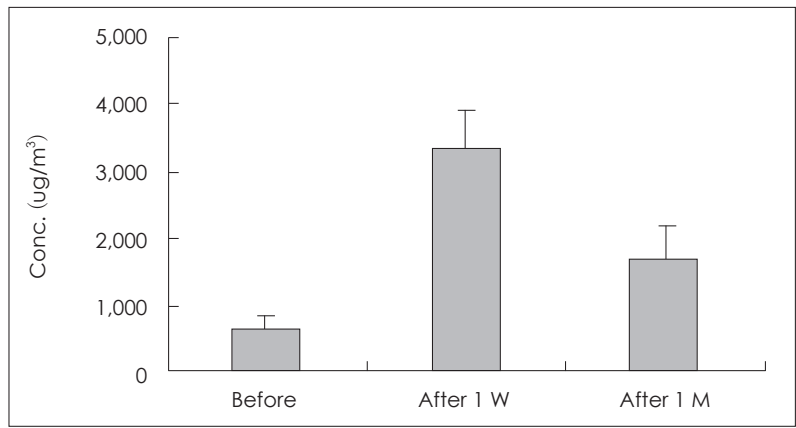

Fig. 1. The mean concentration profiles of Total Volatile Organic Compound (TVOCs) before moving in, one week after moving in, and one month after moving in. The concentrations of TVOCs demonstrate an increase to 5.0 times one week after moving in and 2.5 times one month after moving in.
통, 안구 및 피부 자극 증상과 같은 다양한 불편 증상을 호 소하였으며 기존에 알레르기 비염의 기왕력이 있던 2 명의 대 상자들 역시 증상의 악화를 호소하였다(Table 2). 비강내 사 진을 기초로 이사 전, 후의 비강 상태를 점수화하여 표시한 결과, 이사 후 악화 소견을 점수로 확인하였으며 이의 통계 적 유의성을 확인할 수 있었다 $(p<0.05)(\mathrm{Fig} .3)$.

\section{음향비강통기도검사}

이사 전과 이사 1 주 후, 1 개월 후의 비강내 최소 단면적과 용적의 비교시 각각의 결과값이 감소함을 관찰할 수 있었 고, 통계적 유의성을 확인할 수 있었다 $(p<0.05)$ Fig. 4).

\section{후각 기능 검사}

$\mathrm{T} \& \mathrm{~T}$ olfactometer를 통해 후각 역치의 증가와 후각 인 지의 감소를 관찰할 수 있었으나, 통계적 유의성은 없었다 $(p>0.05)$. 그러나 $\mathrm{CCCRC}$ test상 후각 역치의 증가를 관 찰할 수 있었고, 특히 신축 공동 주택으로 이사 후 1 개월 경

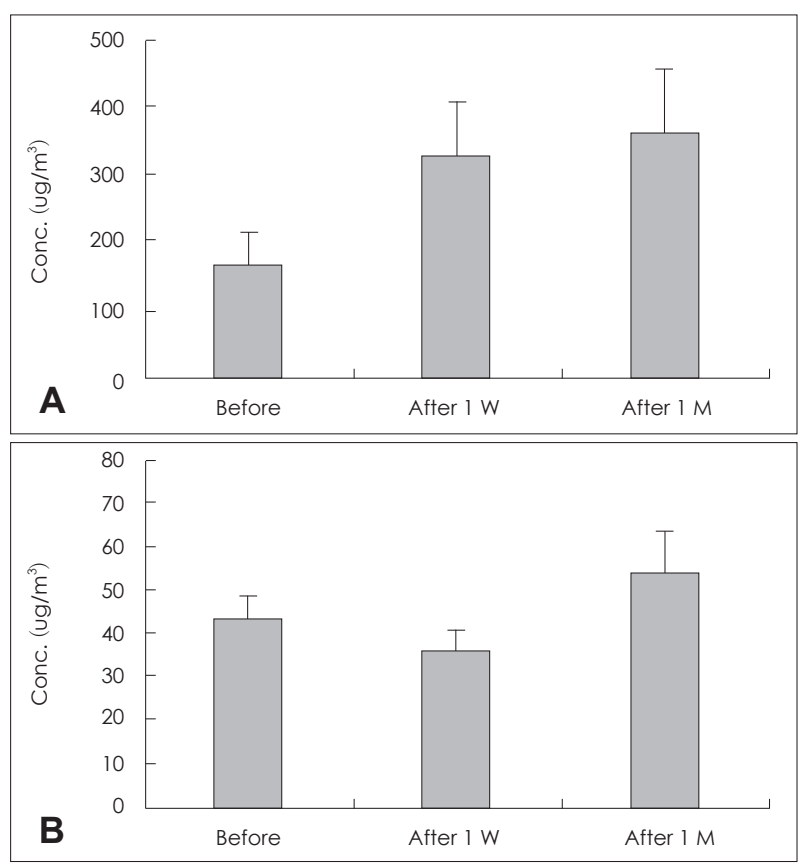

Fig. 2. The mean concentration profiles of formaldehyde $(A)$ and acetaldehyde (B). Formaldehyde and acetaldehyde concentrations show an increase one month after moving into the new apartment, although not as great.

Table 1. The concentrations of five main Volatile Organic Chemicals (VOCs) before moving in, one week after moving in, and one month after moving in

\begin{tabular}{lcccccr}
\hline & MEK & EB & Xylene & Styrene & Tolvene & 5 VOCs \\
\hline Before & 1.0 & 1.0 & 1.0 & 1.0 & 1.0 & 1.0 \\
After 1 W & 42.2 & 3.7 & 4.9 & 7.8 & 8.5 & 13.4 \\
After 1 M & 15 & 2.9 & 3.4 & 5.2 & 4.8 & 6.3 \\
\hline
\end{tabular}

MEK: methylethylketone, EB: ethybenzene 
Table 2. The patients' data

\begin{tabular}{|c|c|c|c|c|c|c|c|c|c|c|c|c|}
\hline \multirow{2}{*}{ No } & \multirow{2}{*}{ Age } & \multirow{2}{*}{ Sex } & \multicolumn{3}{|c|}{ Symptom score } & \multicolumn{3}{|c|}{ CCCRC test } & \multicolumn{2}{|c|}{ Total lgE } & \multicolumn{2}{|c|}{ Nasal smear } \\
\hline & & & Before & After $1 \mathrm{~W}$ & After $1 \mathrm{M}$ & Before & After $1 \mathrm{~W}$ & After $1 \mathrm{M}$ & Before & After $1 \mathrm{~W}$ & After $1 \mathrm{~W}$ & After $1 \mathrm{M}$ \\
\hline$\overline{A 1}$ & 38 & $M$ & 0 & 2 & 2 & 7 & 6 & 4 & 152 & 186 & & \\
\hline $\mathrm{A} 2$ & 35 & $\mathrm{~F}$ & 0 & 1 & 2 & 11 & 12 & 8 & 158 & 172 & & \\
\hline B1 & 44 & $M$ & 1 & 3 & 2 & 7 & 8 & 5 & 166 & 127 & & $*$ \\
\hline B2 & 40 & $\mathrm{~F}$ & 0 & 0 & 2 & 7 & 7 & 8 & 34 & 173 & & \\
\hline B3 & 68 & $\mathrm{~F}$ & 0 & 2 & 3 & 1 & 1 & 1 & 16 & 3 & & \\
\hline B4 & 5 & $\mathrm{~F}$ & 0 & 1 & 1 & 7 & 5 & 4 & 161 & 105 & $*$ & $*$ \\
\hline $\mathrm{Cl}$ & 48 & $M$ & 0 & 1 & 0 & 12 & 10 & 8 & 128 & 109 & & \\
\hline $\mathrm{C} 2$ & 45 & $\mathrm{~F}$ & 0 & 2 & 1 & 12 & 7 & 9 & 137 & 155 & & \\
\hline $\mathrm{C}^{\dagger}$ & 12 & $\mathrm{~F}$ & 1 & 1 & 2 & 12 & 9 & 9 & 387 & 317 & & \\
\hline $\mathrm{C} 4$ & 10 & M & 0 & 1 & 1 & 10 & 5 & 4 & 176 & 144 & & \\
\hline D1 & 42 & $M$ & 0 & 0 & 0 & 9 & 8 & 7 & 45 & 30 & & \\
\hline D2 & 36 & $\mathrm{~F}$ & 0 & 2 & 1 & 9 & 4 & 4 & 174 & 58 & & \\
\hline $\mathrm{D} 3^{\dagger}$ & 11 & $M$ & 1 & 3 & 2 & 9 & 8 & 6 & 926 & 491 & & $*$ \\
\hline D4 & 9 & $\mathrm{~F}$ & 2 & 3 & 3 & 10 & 9 & 8 & 206 & 132 & & \\
\hline
\end{tabular}

* partiipant with infitration of eosinophil in nasal smear, ${ }^{\dagger}$ participant with a history of allergic rhinitis. A, B, C, D: family group, CCCRC: Connecticut Chemosensory Clinical Research Center

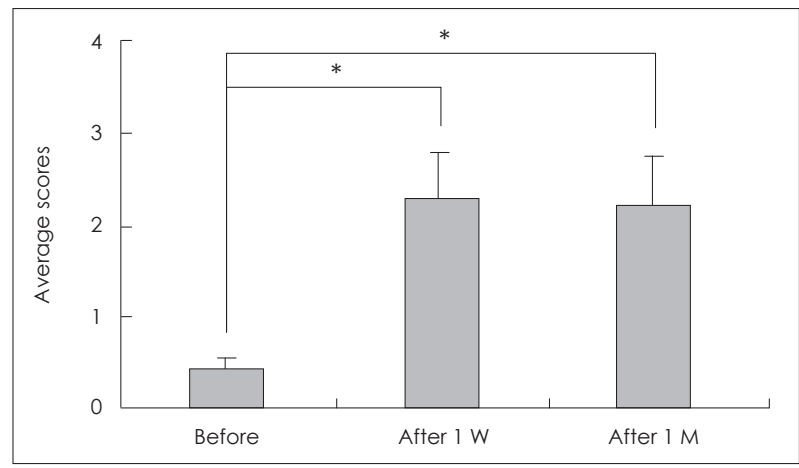

Fig. 3. Average scores of endoscopic findings. The macroscopic changes show a pattern of increase compared with the score before moving in $\left({ }^{*} p<0.05\right)$.

과시 시행한 검사상 통계적으로 유의한 수준의 후각 역치의 증가를 확인할 수 있었다 $(p<0.05)$ (Table 2, Fig. 5)

\section{비즙도말검사}

이사 전 시행한 비즙도말검사상 호산구를 관찰할 수 없었 으나, 이사 후 시행한 검사상 3 명의 대상자에게 있어 조직내 호산구의 침윤을 확인할 수 있었다. 이러한 변화는 주로 소 아에서 볼 수 있었으며 이사 1개월 후 더욱 저명하였다(Table 2).

\section{Multiple Allergen Simultaneous Test(MAST)}

총 $\mathrm{IgE}$ 의 평균 역가는 이사 전 $198 \mathrm{IU} / \mathrm{mL}$ 에서 이사 1 주 후 $157 \mathrm{IU} / \mathrm{mL}$ 로 이사 전후 유의한 수준의 변화가 관찰되 지 않았다 $(p>0.05)$. 알레르기 유발 항원의 평균수는 이사 전 3.7에서 이사 1주 후 6.1 로 통계적으로 유의하게 증가하
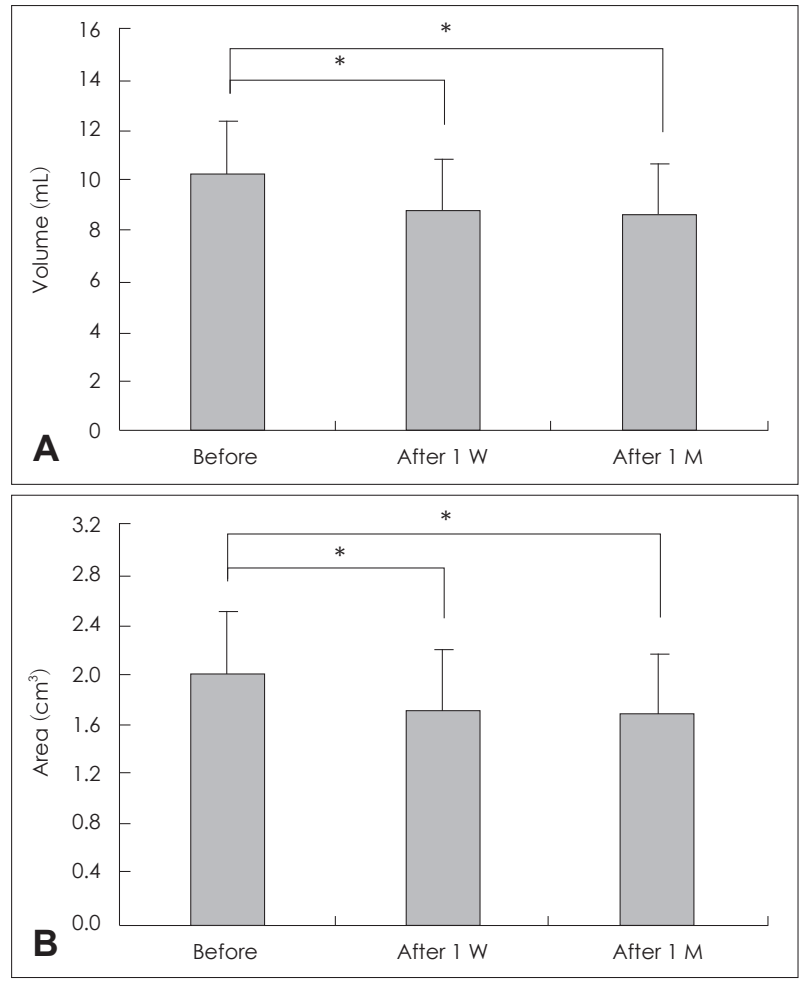

Fig. 4. The results of acoustic rhinometry. Both serial changes of volume (A) and cross sectional area (B) of the subjects' nasal cavities display a pattern of decrease one week and one month after moving into their new apartments $\left({ }^{*} p<0.05\right)$.

였다 $(p<0.05)$.

\section{고 찰}

본 연구를 통해 실내 공기 오염 물질의 증가는 비강내에서 유기적 변화를 일으키고, 이와 함께 후각 감퇴가 발생함을 


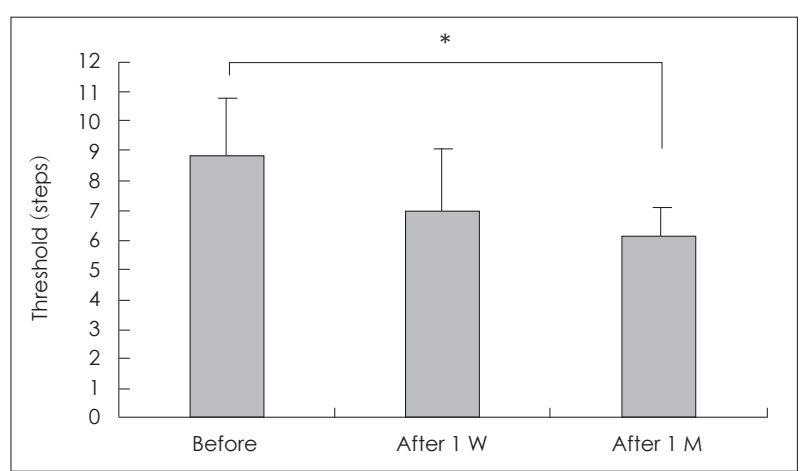

Fig. 5. The result of the Connecticut Chemosensory Clinical Research Center (CCCRC) Test. The change of average threshold one week after moving in was not statistically valuable, but the change one month after moving in was statistically valuable $\left({ }^{*} p<0.05\right)$.

확인할 수 있었다. $\mathrm{Karol}^{10)}$ 은 동물 실험을 통해 실내 공기 오염 물질이 알레르기 반응을 유발하여 전신 열성 반응, 기 관지 질환, 비염 등이 발생한다고 보고하였다. 이외에도 담배 연기, ${ }^{11)}$ toluene 2,4 -diisocyanate(TDI ${ }^{12)}$ 와 같은 여러 화 학 물질이 비강에 영향을 미치는 것으로 보고되었다.

본 연구를 통해 휘발성 유기 화합물과 알데히드 화합물이 신축 공동 주택으로의 이사 1 주 후는 물론 1 개월 후에도 역시 높게 측정됨을 확인할 수 있었다. 특히 개별 분석된 5 종류 의 휘발성 유기 화합물(메틸에틸케톤, 에틸벤젠, 자일렌, 스 티렌, 톨루엔)은 발암 물질로 알려진 유기물들로 이사 1개 월 후에도 증가되어 있음을 확인할 수 있었다. Minami 등8) 은 알데히드 화합물이 신축 공동 주택의 건립 7개월 후 가 장 높은 농도를 보이며, 휘발성 유기화합물의 농도 역시 비 록 감소하지만 같은 시기에 외부 환경보다는 높게 측정되며 이러한 결과는 건립 13 개월 후까지 지속된다고 보고하였다.

실내 공기내 오염 물질의 증가는 다양한 증상과 질환을 유 발할 수 있다. 증상으로는 호흡기 질환은 물론 두통, 피로감 등과 같은 비특이적 증상과 알레르기, 천식과 같은 만성 질 환이 있는 것으로 알려져 있다. ${ }^{67,9)}$ 본 연구의 대상으로 선 정된 4가구의 신축공동주택 모두에서 실내 공기내 오염 물 질의 농도가 높게 나타났고, 대부분의 대상자들은 콧물, 두 통, 안구 자극 증상 등의 불편 증상을 호소하였으며 알레르 기 비염의 기왕력이 있던 2 명의 대상자들 역시 증상의 악화 를 호소하였다. 비 내시경을 통한 이학적 검사상 비강 점막 의 부종, 발적 및 비분비물의 증가 역시 확인할 수 있었다. 내시경 사진을 통한 비강 점막의 평가시 비주기 및 사진 촬 영상의 일관성 등으로 인하여 연구자의 주관이 개입될 여지 가 높으나 최대한 동일 조건하에서 비강내 사진을 얻었고 양측 비강에 대하여 평균값을 구하여 평가하였다. 또한 실 내 공기 오염으로 인해 유발되는 비강내 용적의 변화와 최 소 단면적의 변화를 측정하기 위하여 음향비강통기도검사
를 시행하였고 비강내 용적과 최소 단면적의 즉각적이고 지 속적인 감소를 확인할 수 있었다. 이상의 결과를 기초로 실 내 공기내 오염 물질의 증가가 비강 점막의 염증성 변화와 밀 접한 관계가 있음을 확인할 수 있었고, 이러한 변화가 지속될 때 비 기능의 만성적 변화가 발생함을 유추할 수 있었다.

후각 역치를 평가하기 위하여 $\mathrm{CCCRC}$ 검사를 시행하였 고, 유의할만한 수준의 역치 증가를 확인할 수 있었다. 이 러한 결과는 이사 1 주 후보다는 1 개월 후 저명하였다. 이를 통해 후각 점막이 오염 물질에 지속적으로 노출될 때 후각 기능이 감퇴됨을 알 수 있었다. 이는 비점막의 부종에 의한 기류 차단으로 발생하는 전도성 후각장애와 오염물질 자체 의 영향에 의한 감각신경성 후각장애의 가능성을 모두 고려 해 볼 수 있다. 비내시경 검사를 통해 확인한 바와 같이 실 내 공기 오염은 비강 점막의 변화를 유발하고 이는 전도성 후각장애로 이어질 수 있을 것이다. 실내 공기 오염으로 인 한 감각신경성 후각장애의 가능성을 뒷받침하는 여러 보고 들이 있다. 실내 공기 오염 물질의 작용에 의해 후각의 인지 과정에 장애가 발생13)할 수 있으며 Cassee 등ㄴ)은 동물 실 험을 통하여 이를 확인하였다. 이로 미루어 보아 본 연구를 통해 확인한 실내 공기 오염으로 인한 후각 기능의 감퇴는 이상의 두 가지 기전이 함께 작용하는 것으로 사료된다. 대상 자들에 대한 치료가 완료된 후 비내시경과 후각 검사를 재 시행한다면 이상의 가능성에 대해 보다 의미 있는 자료를 제시할 수 있을 것으로 사료되나 금번 연구에는 포함되지 않 았다.

본 연구에서 이사전과 1 주 후 총 $\mathrm{IgE}$ 의 역가는 유의할 만 한 수준의 변화가 관찰되지 않았다. 이러한 결과는 $\mathrm{IgE}$ 가 천식이나 건초열을 제외한 대부분의 알레르기 질환에서 정 상의 범주에 포함되어 진단적 가치가 크지 않다는 보고 ${ }^{15}$ 와 유사한 결과라 하겠다. MAST 결과상 알레르기항원 특이 $\mathrm{IgE}$ 의 개수가 증가하였다. 이는 $\mathrm{IgE}$ 항체가 검출되는 특이 항원의 종류가 지속적인 항원 노출에 따라 증가하였다는 것 으로 본 연구를 통하여 이에 대한 기전을 밝히기는 불가할 것으로 사료되나 추후 대상군의 수가 증가하고 보다 오랜 기 간 동안 추적 관찰을 통하여 자료를 보강한다면 이에 대한 보다 의미 있는 결과를 얻을 수 있을 것으로 사료된다.

알레르기 반응에 있어서 호산구는 비점막의 염증 반응 및 조직 손상으로 인한 공기 흐름의 저항을 유발한다. ${ }^{16)}$ 본 연 구 대상자들의 비점막에 대한 비즙도말검사상 이사 전에는 조직내 호산구의 침윤을 관찰할 수 없었으나, 신축공동주택 으로 이사 후 반복한 검사에서는 3 명의 대상자에게서 호산 구의 침윤을 확인할 수 있었고, 이는 이사 1 주 후보다는 1 개 월 후 시행한 검사에서 더욱 명확하였다. 이상의 결과는 실내 
공기내 오염 물질이 비강 점막에서 항원으로 작용하여 알레 르기 반응이 발생한다는 본 연구의 가설을 뒷받침한다 할 수 있겠다. 비점막의 알레르기 반응은 호산구 및 점막하 부 종, 혈관 확장, 술잔 세포 및 분비선들의 과증식을 유발한 다. ${ }^{17)}$ 본 연구에서는 신축공동주택으로 이사한 대상자들의 비강 도말시 정상 원주 상피세포의 퇴화를 확인할 수 있었다. 이는 eosinophil cationic protein, major basic protein, eosinophil peroxidase, eosinophil derived neurotoxin 와 같은 세포 독성 물질로 인해 유발될 수 있다. ${ }^{18)}$

알레르기 항원에 노출되었을 때 급성기 반응으로 콧물, 재채기, 코막힘 등의 증상이 발생한다. 그러나 동일 알레르기 항원에 만성적으로 노출되었을 때 비강의 과민반응은 감소 하고 상기의 급성기 증상도 감소하게 된다. ${ }^{19)}$ 그러므로 신축 공동주택으로 이사 후 보다 오랜 기간 동안 비강내 반응의 추이를 지켜보는 것이 필요할 것으로 사료된다. Connell ${ }^{20)}$ 은 알레르기 항원에 의해 유발된 비점막의 과민반응은 가역적 이며 회복을 위한 시간은 항원에 노출되는 기간과 밀접한 관 계가 있다고 보고하였다. 향후 보다 많은 시험군을 대상으로 오랜 기간 동안 경과 관찰을 통해 자료를 보강한다면 신축건 축물에서 발생하는 실내 공기내 오염 물질의 증가와 비강 점 막의 유기적 변화에 대한 메커니즘을 보다 설득력 있게 설명 할 수 있을 것으로 사료된다. 또한 이러한 결과를 기초로 신 축공동주택의 실내 공기에 대한 권고 기준 값을 설정하고 규 제하기 위한 보다 객관화된 지표를 제공할 수 있을 것이다.

\section{Acknowledgments}

This work was supported by a grant from the BioGreen 21 Program (No. PJ007170201005), Rural Development Administration, Republic of Korea.

This work was carried out with the support of "Cooperative Research Program for Agriculture Science \& Technology Development (PJ007676201002)" Rural Development Administration, Republic of Korea.

\section{REFERENCES}

1) Norbäck D, Edling C. Environmental, occupational, and personal factors related to the prevalence of sick building syndrome in the general population. Br J Ind Med 1991;48(7):451-62.

2) Norlen U, Andersson K. An indoor climate survey of the Swedish housing stock (the ELIB study)". In: Proceedings of indoor air 1993, Helsinki, international conference on indoor air quality and climate, vol 1, pp 743-748.
3) Yura A, Iki M, Shimizu T. [Indoor air pollution in newly built or renovated elementary schools and its effects on health in children]. Nippon Koshu Eisei Zasshi 2005;52(8):715-26.

4) Li CS, Hsu CW, Tai ML. Indoor pollution and sick building syndrome symptoms among workers in day-care centers. Arch Environ Health 1997;52(3):200-7.

5) Apter A, Bracker A, Hodgson M, Sidman J, Leung WY. Epidemiology of the sick building syndrome. J Allergy Clin Immunol 1994;94 (2 Pt 2):277-88

6) World Health Organization. Indoor air pollutants: exposure and health effects report on WHO meeting, vol 78. WHO Resional Office for Europe. EURO Reports and Studies;1983, p.78, 1-48.

7) Wittczak T, Walusiak J, Pałczyński C. [Sick building syndrome" a new problem of occupational medicine]. Med Pr 2001;52(5):36973.

8) Minami T, Matsumoto H, Kondo F, Yamada S, Matsumura T, Ando $\mathrm{M}$, et al. [Variation in indoor air pollutant concentrations with time in a newly constructed private house]. Nippon Koshu Eisei Zasshi 2002;49(3):211-21.

9) Garrett MH, Hooper MA, Hooper BM, Rayment PR, Abramson MJ. Increased risk of allergy in children due to formaldehyde exposure in homes. Allergy 1999;54(4):330-7.

10) Karol MH. Allergic reaction to indoor air pollutants. Environ Health Perspect 1991;95:45-51.

11) Groneberg DA, Heppt W, Cryer A, Wussow A, Peiser C, Zweng M, et al. Toxic rhinitis-induced changes of human nasal mucosa innervation. Toxicol Pathol 2003;31(3):326-31.

12) Tanaka $K$, Okamoto $Y$, Nagaya $Y$, Nishimura F, Takeoka A, Hanada $\mathrm{S}$, et al. A nasal allergy model developed in the guinea pig by intranasal application of 2,4-Toluene diisocyanate. Int Arch Allergy Appl Immunol 1988;85(4):392-7.

13) Cometto-Muñiz JE, Cain WS, Abraham MH, Gola JM. Chemosensory detectability of 1-butanol and 2-heptanone singly and in binary mixtures. Physiol Behav 1999;67(2):269-76.

14) Cassee FR, Arts JH, Gronten JP, Feron VJ. Sensory irritation to mixtures of formaldehyde, acrolein, and acetaldehyde in rats. Arch Toxicol 1996;70(6):329-37.

15) Ishizaka $K$, Ishizaka $T$. The significance of immunoglobulin $E$ in reaginic hypersensitivity. Ann Allerg 1970;28(5):189-202.

16) Jang AS. Nasal eosinophilic inflammation contributes to bronchial hyperresponsiveness in patients with allergic rhinitis. J Korean Med Sci 2002;17(6):761-4.

17) Holopainen E. Nasal cytology as a nasal test. Rhinology 1976;14(1): 29-35.

18) Flavahan NA, Slifman NR, Gleich GJ, Vanhoutte PM. Human eosinophil major basic protein causes hyperreactivity of respiratory smooth muscle. Am Rev Respir Dis 1988;138(3):685-8.

19) Wayoff M, Moneret Vautrin DA, Gazel P, Simon C, Storme X. [Etiopathogenic diagnosis of vasomotor rhinitis]. Acta Otorhinolaryngol Belg 1980;34(2):119-30.

20) Connell JT. Quantitative intranasal pollen challenge. II. Effect of daily pollen challenge, environmental pollen exposure, and placebo challenge on the nasal membrane. J Allergy 1968;41(3):123-39. 